\title{
Dissemination of English Culture in Chinua Achebe's No Longer at Ease
}

\author{
Bahman Zarrinjooee \\ Faculty of Postgraduate Department of English Language and Literature, Islamic Azad University, Boroujerd, Iran \\ E-mail: bahmanzarrinjooee@yahoo.com \\ Shahla Khatar (Corresponding author) \\ Faculty of Postgraduate Department of English Language and Literature, Islamic Azad University, Boroujerd, Iran \\ E-mail: khataar.shahla@gmail.com
}

Doi:10.7575/aiac.alls.v.7n.4p.231

URL: http://dx.doi.org/10.7575/aiac.alls.v.7n.4p.231
Received: 16/04/2016

Accepted: 26/06/2016

\begin{abstract}
This paper deals with Chinua Achebe's (1930-2013) No Longer at Ease (1960) which depicts the dissemination of English culture in Nigeria and its effects on the life and identity of Obi Okonkwo, the Western educated male protagonist. The focus of this paper is on the dissemination of English culture and submission of Nigerian culture in order to represent the inferiority of Nigerians. Edward Said's (1935-2003) attempts regarding Orientalism and Frantz Fanon's (1925-1961) issues relating inferiority of the indigenous people caused by colonization are used in this paper. The colonisers affect the life, mind, culture, and identity of the colonized through various ways such as education, religion, and language. Such effects cause some cultural transformation and changes in language of the colonized people. Moreover, the colonizer through stereotyping the colonized people assumes them as other. Indeed, the colonizer imposes his/her superiority on the natives who try to assimilate themselves with the colonizer. Achebe in his novel shows how this effort causes some binary relation among the characters. The novel shows the difference between two cultures, and Achebe puts emphasis on the superiority of English culture and depicts how colonialism and Western orientalism produce stereotyped images of Nigerians and Obi as corrupt. Consequently, such features have great impressions on the mind of Nigerians, which results in inferiority complex. Such characteristic invites the Nigerians to follow European's value and forget their own culture, which is resulted in the rejection of native values.
\end{abstract}

Keywords: Binary Relation, Colonization, Cultural Transformation, Cultural Dissemination, Orientalism, Stereotyping

\section{Introduction}

Albert Chinualumogu Achebe (1930-2013), generally known as Chinua Achebe, was born in Ibo village of Ogidi in southeastern Nigeria. Although Achebe's parents converted to Christianity, but they also admired their traditions. Therefore, his childhood was regarded by rich ambivalence of heritage. He was accepted at the University College in Nigeria on a scholarship. At first, he studied medicine, but he changed it to English-like the protagonist of No Longer at Ease (NLE), Obi.

This paper is a review of Chinua Achebe's No Longer at Ease through the filter of Orientalism. The orientalists' notions about Africa and the colonialist's attitude towards Africans are analyzed. In addition, the effect of colonialism and imperialism on the minds of the black characters will be studied and it will be shown how Western orientalist and colonialist education shape the "self image" and identity of the blacks.

No Longer at Ease is about a civil servant who is finally corrupted by the corruption of society of Lagos. The protagonist is Obi Okonkwo, a grandson of Achebe's first protagonist in Things Fall Apart. Obi is struggling against many obstacles. He is trying to live a decent life while he is trying to satisfy his family, his home village, and larger society. Unable to make a balance between his values and the expectations of the society, Obi experiences a total breakdown.

\section{Materials and Methods}

Through the theories of Edward Said (1935-2003) and Frantz Fanon (1925-1961), this paper shows how colonisers influence the identity and culture of the colonized nations. These critics try to examine the colonized people as the victims of Western hegemony, and investigate the ways in which colonial discourse acted as an instrument of power. Western writing about the Orient represents it as weak, irrational, and feminine in contrast to the strong, rational, and masculine West.

The binary relation is based on a psychological desire to create a cultural hierarchy between East and West. This binary opposition is reinforced by the stereotypical images and archetypes that are constructed by literary texts and historical records about the East. In Orientalism (1978), Said argues that the cultural inferiority of the Orient is attributed to the 
nature or 'essence' of the Orientals. Said uses the ideas of power and knowledge, which are analyzed by Michel Foucault (1926-1984). Said finds out beyond the knowledge about the Orient, which is produced by European hegemony. This knowledge is not authentic, which privileges the culture of the European, and marginalizes nonEuropean.

Another significant issue, which makes the black to accept the superiority of the white culture is the colonizers' own discoursal patterns and their stereotypical images of Africans. Fanon argues:

I begin to suffer from not being a white man to the degree that the white man imposes discrimination on me, makes me a colonised native, robs me of all worth, all individuality, tells me that I am a parasite on the world, that I must bring myself as quickly as possible into step with the white world, that I am a brute beast, that my people and I are like a walking dung-heap that disgustingly fertilises sweet sugar cane and silky cotton, that I have no use in the world. (2008: 73)

Fanon, in Black Skin, White Masks, consistently argues that the encounter of black and white people does not lead to the assimilation of black and white identity. For one thing, the white community does not allow the black community to become integrated into their supposedly superior culture. If such a thing happens, the colonizers' claim to political domination and economic exploitation becomes null and untenable. No genuine equality can be allowed, although some moments of controlled similarity will always be allowed to create momentary relief among the blacks. Unlike those theorists who argue for the possibility of assimilation and equality, Fanon advocates a revolutionary and radical response on the parts of all oppressed and marginalized groups to return to one's traditions and values, and to reject the settler's value:

Thus the native discovers that his life, his breath, his beating heart are the same as those of the settler. He finds out that the settler's skin is not of any more value than a native's skin; and it must be said that this discovery shakes the world in a very necessary manner. All the new, revolutionary assurance of the native stems from it. For if, in fact, my life is worth as much as the settler's, his glance no longer shrivels me up nor freezes me, and his voice no longer turns me into stone. I am no longer on tenterhooks in his presence; in fact, I don't give a damn for him. Not only does his presence no longer trouble me, but I am already preparing such efficient ambushes for him that soon there will be no way out but that of flight. (1963: 44)

The colonized prepared to reject the settlers. The native elites, who were educated in the colonizers' culture, played an important role in decolonization and independency. The process of colonization creates the sense of inequality and inferiority among the people in the colonized culture. Such people see themselves as subjugated; therefore, they imitate the European and identify themselves with the European. Frantz Fanon argues a black man who is internally inflicted with 'inferiority complex' attempts to emulate white values in all aspects of his life. In The Wretched of the Earth (1960-61), he declares "it is true, for there is no native who does not dream at least once a day of setting himself up in the settler's place" (38). This process, which is the result of hegemony of white culture, results in the rejection of native values by the black people; and westernization is achieved only at the cost of self-disrespect. Such a position creates abnormality and psychological problems.

Through the above-mentioned theories of the critics, this paper shows the effects of the colonization on the life of the characters in Achebe's No Longer at Ease. In relation to Said's theory, the Europeans try to make stereotypes about the Nigerians and display them as corrupt in need of Europeans in order to be civilized, which is depicted in the novel. In addition, the novel, which focuses on the inferiority of the indigenous people and their identification with Europeans, is a good example of Fanon's notion about 'inferiority complex', which is caused by colonization.

\section{Results and Discussion}

Colonialism can be explained as the control and domination of one country over other countries, not only over lands, but also over the language, religion, and lifestyle of the people. In human history, colonialism can be observed as the destruction of cultural heritage and value systems of indigenous people. Ania Loomba defines colonialism as "the conquest and control of other people's land and good" (2). Edward Said argues that colonialism is the result of imperialist operation, which suggests an unequal relationship. One of the main purposes of colonialism is to change the life of indigenous people.

Said is against stereotypical representations of non-Europeans in general terms as 'Black,' 'Oriental,' etc. For him, these general descriptions humiliate the complexity and variety of other cultures and reduce them to a few negative concepts. For him, these negative notions are meant to represent the non-Europeans as inferior to Europeans and this hierarchy is used to justify colonialism and the domination of West over East.

\section{Orientalism, Stereotype and Image of Colonized Africa}

During colonization, the colonizers create the image of the orient or non-Europeans in different ways. Said, in Orientalism, asserts, "the Orient (Third world countries) has helped to define Europe (or the west) as its contrasting image, idea, personality, experience [...] The Orient is an integral part of European material civilization and culture" (2). He claims that the history and culture in the Oriental countries depend on their connection with the West; 
consequently, such dependency makes their self-image. The colonizers situate the colonized in their own ways; therefore, the colonized never identify him/her self with the colonizers that enable them to expand their culture and attitude.

One significant aspect of Achebe's novel is its description of British colonialists' attitude towards Nigeria and Nigerians. Achebe poses Mr. Green, Obi's boss, as the representative of British colonialists in Nigeria. As Obi, the protagonist of the novel, imagines, Mr. Green resembles the British characters in Joseph Conrad's Heart of Darkness (1899). Prior to his contact with Africa, Mr. Green had imagined and portrayed the 'dark' continent. His created image of Africa and its stereotype cast a land with dark colours and thick bushes waiting for the arrival of human and establishment of civilization. As Obi imagines, Mr. Green must have become very disappointed with real Nigeria when he arrived in the country for the first time, since the land was not as dark and bushy as he had imagined. However, Mr. Green continued to adhere to his false beliefs about Nigeria and whenever people and situations failed to satisfy his expectations, he started cursing and swearing:

It was clear he loved Africa, but only Africa of a kind: the Africa of Charles, the messenger, the Africa of his garden- boy and steward-boy. He must have come originally with an ideal---to bring light to the heart of darkness, to tribal headhunters performing weird ceremonies and unspeakable rites. But when he arrived, Africa played him false. (NLE 107)

This story proves Said's description of Orientalism as a field of knowledge comprising imaginary lands, not real lands. Said argues that Orientalism is not concerned with "correspondence between Orientalism and the Orient, but with the internal consistency of Orientalism and its ideas about the Orient" (5). According to Said, as the ideas about the Orient have always been imaginary and formal, they create a seamless follow of all writing genres, from sociology to literature, and from philology to historiography.

In the opening chapter of the novel, Mr. Green is playing tennis with a member of the British Council. Meanwhile, during which he discusses the case of Obi and his acceptance of bribes. Mr. Green is not surprised at Obi's behaviour because, according to him, "the African is corrupt through and through":

I cannot understand why he did it," said the British Council man thoughtfully. [...] "I can," said Mr. Green simply. "What I can't understand is why people like you refuse to face facts." Mr. Green was famous for speaking his mind. He wiped his red face with the white towel on his neck. "The African is corrupt through and through". (NLE 3)

This scene illustrates only one of the many scenes of Mr. Green's attitude towards Africa as the negative counterpart 'other' of Europe. He is a typical colonialist who has a firm belief in the positive effects of colonialism. According to him, Britain has done its best to bring "education" to Africa, and he laments the fact that the Education in England has not improved Obi and Nigeria. He tells Obi, "I think Government is making a terrible mistake in making it so easy for people like that to have so-called university education. Education for what?" (NLE 116).

By reminding Obi of his debts, Mr. Green tries to play the role of a protector for Obi. According to Said, orientalists imagined the Orientals as lazy and ineffectual in order to justify their own role as colonizers. As Said argues in many cases, 'irrationality' and 'laziness' are among the attributes that the Orientalists usually attach to the Orientals. Accordingly, by trying to manage Obi's financial affairs, Mr. Green is satisfying his own wishes. He likes to consider Obi as a lazy and irrational. In this way, he justifies his own stay in Nigeria. In other words, he thinks that the Nigerians need him and other colonisers, because they cannot manage their own lives.

Corruption and guilt are the colonized characteristics, in contrast, the colonisers are right and justice, and "the native is always presumed guilty" (Fanon 53). Achebe skillfully depicts the sense of guilt among the Ibo people. Obi, who is accused of bribery, does not feel pity in the court. The courtroom is full of the people who left their job to hear the vote; some of them pay money to doctors to obtain paper of illness for that special day. Such corruption, like bribery, pay money for certificate paper, and abortion are interwoven in a colonized nation, justifying their deserve punishment.

\section{Master/Slave: Binary Relation among Characters}

According to Hegel, for each slave group, there should be a master one. The master in order to recognize himself needs and wants slave's existence and if there is no slave, there might not be a master. Master and slave identify their being in the relation of each other; therefore, the existence of the master depends on the existence of the slave.

As Obi tells readers, the times of Mr. Green are different from early colonial days when a British official was free to treat Africans as he liked. However, Mr. Green is blind to the changes in Nigeria and continues to use the lens of a typical colonialist's mentality to see the world. For example, when he orders beer, he tells one of the men near him to bring "one beer for this master" (NLE 4). The encoded master/slave expressions in his diction, shows his colonial mentality and his false image of the Nigerian people. This way of self-expression corresponds with Said's definition of orientalism as a kind of knowledge, which remains blind to historical changes.

According to Said, the continued insistence on "Oriental backwardness" strengthens the superiority of Western civilization and serves as a justification for the West's imperialist and colonialist projects on a humanitarian basis (7). This higher-lower status relation is based on a psychological desire to create a cultural hierarchy between West and 
East. Meanwhile, the loaded stereotypical images in the literary texts composed about the Orient have reinforced the double-edged classification.

Mr. Green has a habit of reminding Obi of his debts and bills. For him, even the "educated" Africans are not civilized enough to have a program for their life and think about tomorrow. He tells Obi, "in a country where even the educated have not reached the level of thinking about tomorrow, one has a clear duty" (NLE 95). As Obi thinks, Mr. Green seems to love Africa, since he is spending all his time working in this country and concerning for its people, including Obi. However, as Obi truly realizes, Mr. Green does not like the real Nigeria, but the Nigeria of his imagination. He likes the Nigeria of thick bushes, dirty natives, and submissive servants. He likes his office, because his submissive workers, stewards, and messengers who give him a pleasing self-image as a colonial master surround him.

Mr. Green is reluctant to accept and love educated people like Obi, since they refuse confirming his belief in Africa's backwardness. Interestingly, when Obi is accused and caught for accepting bribes, he celebrates the event because it proves his opinion towards Africans as corrupt and unchangeable. According to Green, Nigerians go to Universities "to get as much as they can for themselves and their family. Not the least bit interested in the millions of their countrymen who die every day from hunger and disease" (NLE 116).

Mr. Green is patronizing and proud. His treatment of Nigerians reminds Obi of a certain British man, a school inspector, whom Obi had met during his school days. Obi remembers a day in school when the British school inspector slapped a Nigerian headmaster in front of the students as punishment for the headmaster's failure in an official matter.

For Obi, Nigeria has changed and white men can no longer act as boldly as they did in those days. "That was twenty years ago. Today few white men would dream of slapping a headmaster in his school and none at all would actually do it. Which is the tragedy of men like William Green, Obi's boss" (NLE 65). In those days, 'old African' men were submissive, because they worshipped white men. The new generation of Nigerians, Obi included, have a higher selfrespect and no longer accept English men as their masters.

However, Mr. Green cannot recognize the difference between the new generations of Nigerians and the generation of the headmasters. He openly criticizes the educated Nigerians and insists that education of Africans is a waste of time, since they are unable to improve themselves. His treatment of Obi, shows his pride and his disgust of Obi as an educated African:

Obi had already met Mr. Green that morning. As soon as he had arrived he had been taken in to be introduced to him. Without rising from his seat or offering his hand Mr. Green muttered something to the effect that Obi would enjoy his work; one, if he wasn't bonelazy, and two, if he was prepared to use his loaf. "I'm assuming you have one to use," he concluded. (NLE 65)

Mr. Green thinks of Nigeria as a typical oriental society bare of history or historical progress. The predominance of corruption and laziness cripple the society to change and recover from the evil of poverty and backwardness. Such a disappointing image of the 'Orient,' as a society without history, persuades some critics to conclude that the social change can be achieved merely by the hands of colonial powers.

\section{Dissemination of European Culture}

Understanding a society's tradition and belief equals understanding its cultural identity. In fact, every nation is a set of traditions and customs that construct the individuals' life style. Tribal and colonized nations have been transformed because of their cultural alienation of their traditions. This change can be attributed to colonization due to its domination over a country in general, and over its culture, in particular.

The wave of European cultural invasion over non-Europeans disturbs the stability of the traditional culture. The dominated power of the colonizers unfolds in two ways. First, it expands its trade, Christianity, and education, and transforms the indigenous people's cultural identity. Simultaneously, the culture of the colonized is changed and a new culture emerges. Albert Memmi (1920- ), in The Coloniser and the Colonised (1991), argues that the colonizer imposes his superiority on the beliefs and culture of the natives. During colonization, the colonizer becomes "an illegitimately privileged usurper" (9). According to Memmi, the colonizer continues this condition, which brings his superiority.

One of the significant themes in Achebe's narrative is the stream to show that the experience of colonialism and the dissemination of European culture in Nigeria have influenced the formation of the new cultural identity and distortion of African people's self-image and cultural identity. As Achebe shows throughout his novel, European education, especially when it concerns the study of African culture and people, is thoroughly through the lens of Orientalists, it is based on an essential difference between Europeans and non-Europeans.

Western orientalists have represented Europeans as civilized, educated, and powerful while non-Europeans as backward, lazy, and powerless. This kind of image-formation is enlarged by the experience of colonialism, thus, it affects the mentality of both colonizers and the colonized. Achebe's portrayal of the black characters discloses the line of thinking in Nigerians, especially those who are similar to Obi, studied in and graduated from the British universities have some of Mr. Green's illusions in common.

Obi is a typical educated young man who has a firm belief in the positive effects of European education on Nigeria. He has no respect for "old Africans" whom he considers as the roots of all problems in Nigeria. The term old Africans in 
his viewpoints refers to those Africans who still occupy some offices and lack ample education and skill to cope with the circumstances of modern Nigeria:

Obi's theory that the public service of Nigeria would remain corrupt until the old Africans at the top were replaced by young men from the universities was first formulated in a paper read to the Nigerian Students' Union in London. But unlike most theories formed by students in London, this one survived the first impact of homecoming. (NLE 38)

Two distinct reasons can be recited for Obi's disrespectful treatment towards old Africans. The first reason stems in the debris of relationship between the whites and the blacks, which was based on master/slave relationship. For example, the relationship between Mr. Omo and Mr. Green reminds him of the relationship between the black headmaster and the white school inspector in Obi's school days. Mr. Omo is a typical old African, a submissive servant who calls Mr. Green as his master. The second reason of Obi's hatred of old Africans reverberate his firm beliefs that ring the importance of education and insignificance of African traditions and culture. Obi himself does not realize the depth of his Westernization. Although he loves his country, he is deeply attracted by European culture and when he returns from England he can no longer retains a peaceful relationship with his family, the Umuofia Progressive Union and the whole culture of old Nigeria.

In some ways, Obi looks like Europeans rather than the Ibo. He does not allow Umuofia Progressive Union, his father, and his tradition to pass an opinion on his decisions. He decides on his education and marriage. His European education alienates him from his people:

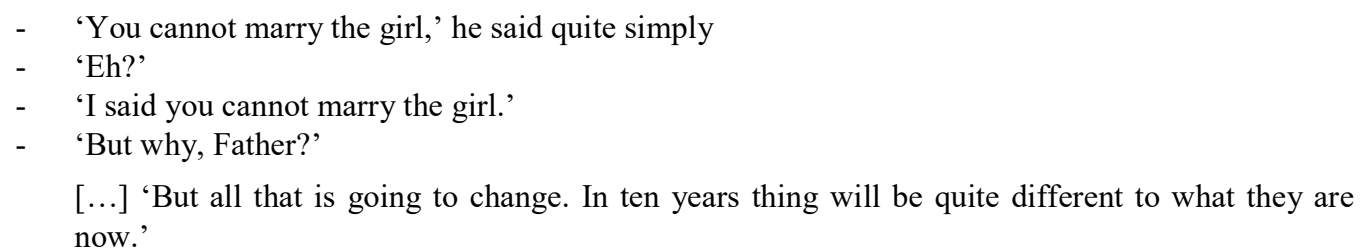
[...] Obi repeated his point again. What made an $o s u$ different from other men and women? Nothing but the ignorance of their forefathers. (NLE 132-34)

Obi's parents are hurt as he disobeys their tradition. Osu is an outcast in Nigerian traditional culture to marry him/her is forbidden. Obi is European in his beliefs and he is ready to marry an osu. However, the society and his parents perplex Obi's thoughts, and he is caught between two worlds, Christianity and modernity or to convention and tradition. Here the cultural conflict has multiple dimensions.

In the tribal society, there is no mention of adultery, and marriage connects to polygamy. Nevertheless, in No Longer at Ease, Achebe shows the problem of marriage among Western educated elites and for the first time depicts the sexual affair- outside of marriage- between Obi and Clara. It is due to their Westernized education and European life style. This novel displays a record of the conflict between Ibo's society and colonial domination that attacks on personality, psyche, and identity of an African character.

Another sign of the spread of European culture in No Longer at Ease is the natives' attitude toward government. "In Nigeria the government was 'they'. It had nothing to do with you or me. It was an alien institution and people's business was to get as much from it as they could without getting into trouble" (NLE 33). Because most of the people in Umuofia or tribal society do not take part in government, they do not have a sense of belonging. The people of Umuofia call the person who has a job in government as a holder of "European post" (NLE 92). Therefore, the mind of such people always struggles with Europeans and their cultural superiority.

\section{European Education as a Way of Cultural Transformation}

Through educational system, the myth of inferiority complex is internalized by the colonized. It means that the colonizers form the knowledge of their colonies. In such a process, the colonized begins hating his selfhood, language, history, religion, and values. Therefore, the native elites accept the colonizer's attitude, morality, and values. In a colonized country, European system of education trains native elites in a way to reject their traditional rules. The elites set a touchstone of the colonizer's value system as a scale to evaluate their assimilation within such a system. Selfesteem for the elites is the decolonization of mind and identity of the colonizer's bandage and the development of a real tribal and cultural identity.

Educated people play an important role in tribal colonized society. In Achebe's Nigeria, education is considered as greatness and villagers compete with each to send their sons to European countries. "Titles are no longer great, [...] Greatness is now in the things of the white man. And so we too have changed our tune. We are the first in all the nine villages to send our son to the white man's land" (NLE 54).

As Obi returns from England, he exhibits the first signs of his disrespect toward the local tradition, and he reshapes his previous belief that the Nigerian education system is capable of changing the society for better. Meantime, despite his family and Umuofia Progressive Union's contest, he decides to marry Clara that is another step in overlooking tradition. 
Joseph, Obi's friend, stunned by Obi's behaviour, tries to put it in Obi's mind that education and educated people are unqualified to cause revolution and they are only "pioneers":

"Look at me, Obi." Joseph [...] "What you are going to do concerns not only yourself but your whole family and future generations. [...] In future, when we are all civilised, anybody may marry anybody. But that time has not come. We of this generation are only pioneers." (NLE 75)

Joseph believes that all aspects of reform in Nigeria should be calculated and cautious. In contrast, Obi hastens to put the new values in the place of old ones. Obi accuses Joseph of having a colonial mentality and tells him that being a pioneer means that he should make great changes to the Nigerian society.

On the one hand, Obi's thinks he betrays his cultural heritage when he studies English literature. He loves his native language and at the same time, he is delightful with English language. Obi like the other elites is torn between his thinking in Ibo community and the new ideas, which are developed by his European education:

Four years in England had filled Obi with a longing to be back in Umuofia. This feeling was sometimes so strong that he found himself feeling ashamed of studying English for his degree. He spoke Ibo whenever he had the least opportunity of doing so. Nothing gave him greater pleasure than to find another Ibo-speaking student in a London bus. [...]It was humiliating to have to speak to one's countryman in a foreign language, especially in the presence of the proud owners of that language. They would naturally assume that one had no language of one's own. (NLE 49-50)

On the other hand, Obi's shifting from studying law to studying English literature indicates his devotion to English culture. Chapter three of the novel shows that Obi has a deep interest in the T. S. Eliot's poetry, a poet who believes in the superiority of the tradition of English literature and the values of Western classics. Clara, who is alike Obi in studying in England, does not understand Eliot's poetry, but she enjoys movies made in the West. Accordingly, both of these characters are infatuated with the Western culture and its products.

Devotion to European culture, which is a product of colonialism, can be seen in the behaviour of many other black characters. The members of the Umuofia Progressive Union are very proud of Obi because, as they proudly repeat it, he was graduated from England. Obi's family and the people of his home village hold a feast for him and they are very eager to see how education in England has transformed Obi.

The reader can expect people's bewilderment of Obi's conducts, which resemble a person who has just graduated from an English university. When Obi returns from England, he decides to stay with Joseph instead of staying at a hotel room that the Umuofia Progressive Union has reserved for him. This decision surprises Joseph, because he thinks it is not proper for a man with a degree from an English university to stay in a friend's home:

"I'm moving out of this filthy hotel tomorrow morning and coming into your place."

Joseph was amazed, but also very pleased. He tried to raise another objection, but it was clear his heart was not in it.

"What will the people of other towns say when they hear that a son of Umuofia returned from England and shared a room in Obalende?"

"Let them say what they like." (NLE 36)

Here, Joseph represents the opinion of Nigeria's public and their estimation of European Education. Consequently, when Obi appears at his graduation ceremony, which is held by Umuofia Progressive Union, Joseph and others cannot hide their frustration over Obi's casual dress and his informal English. The president of the Umuofia Progressive Union, contrarily, is dressed for the occasion and gives speech in full and formal English raising the audience's enjoyment and appreciation. The audience's interest in the president's fluent English shows the extent of their attraction to the language of the colonisers.

In the same chapter and in another setting, when Obi and Joseph go to a restaurant, which is owned by an old English woman, Obi surprises Joseph by his preference of Nigerian food over English food. When Joseph expresses his surprise at Obi's taste, Obi tells him that he likes Nigerian food better, because he is tired of eating "boiled potatoes" (NLE 34). It seems that Obi himself is not fully aware of his status and prestige as a man who has just been graduated from an English university. The narrator mentions that this restaurant is a place for English colonialists and well-to-do Africans who visit the place for English food. It is among the places where the educated and wealthy Nigerians go to visit Europeans and learn European ways of life.

Despite all concern for their country, educated Nigerians admire English men consciously and unconsciously. The black skinned Minister of the State, Sam Okoli, acknowledges the white men's part in helping Nigeria. At the same time, from his viewpoint, Nigeria belongs to the black and white men must leave it, though, he thinks that the white men enabled the black to rule their own country. 


\section{The Role of Language in No Longer at Ease}

One of the significant aspects of 'imperial oppression', according to Bill Ashcroft and others, in The Empire Writes Back (2002), is the control over language. Language becomes an instrument for the colonizer to construct 'truth' and 'reality'. The educational system marginalizes all different dialects of language, and makes the 'standard' version of language as the rule. Therefore, "the English language has been used in these societies, and to indicate their own sense of difference" (8).

Language is not only a way of communication, but also conveys culture and history. Language is not separated from human being, his worldview, and history. Language carries the entire system of values by which a person comes to understanding himself. According to Ngugi wa Thiong'o (1938- ), in Decolonising the Mind: The Politics of Language in African Literature (1987):

Language as communication and as culture are then products of each other. Communication creates culture: culture is a means of communication. Language carries culture, and culture carries, particularly through orature and literature; the entire body of values by which we come to perceive ourselves and our place in the world. How people perceive themselves affects how they look at their culture [...] Language is thus inseparable from ourselves as a community of human beings.

In order to control colonized people's culture during colonization, the colonizer should control the native language, which is a vehicle of "self-definition in relationship to others" (ibid). Through language, the colonizer destroys and/or minimizes culture, history, religion, and mentality of the colonized nations. Therefore in colonial period, colonized people acquire the language of the colonisers and represented it as natural. By using European language, Europeans create a sense of lack of knowledge among non-Europeans (Africans); therefore, language is used to subjugate nonEuropeans.

Ngugi wa Thiong'o declares that in order to keep African culture alive, African writers have to write in their native language. He also criticizes Achebe for his writing in English, but Achebe prefers English as the language for No Longer at Ease and most of his novels. For Achebe, language is an instrument to describe cultural attitude of colonial Nigeria. In No Longer at Ease, language is one of the themes of the novel, and Achebe uses three languages in this novel; Ibo, Pidgin, and English.

Ibo is the language of the Ibo people of Eastern Nigeria. Obi and other characters speak Ibo as well as English. Ibo depicts the language of traditional Africa and brings a sense of kinship. Unlike the Europeans who only use English, the native characters intentionally use their own Language and the European language and move between two worlds. Europeans and Nigerians use English as a colonial language as a common way of communication, but Ibo is a special language to the Ibo culture, and becomes a private language to the Ibo people.

Obi uses English language at work, but when he wants to speak with his people, because of the European existence in his room, Miss Tomlinson who shares her room in the office with Obi, Obi turns to Ibo; "he sent for Charles and asked him in Ibo why he had not fulfilled his promise" (NLE 96). In another scene in the novel, Obi meets Mr. Mark, a countryman who tries to bribe Obi. Mr. Mark speaks English perfectly and at first, he greets Obi in English, but when Mr. Mark saw Miss Tomlinson, he turns to Ibo: “if you don't mind, shall we talk in Ibo? I didn't know you had a European here" (NLE 86).

English as a public means of communication in Nigeria is not an appropriate language to talk about sensitive topics such as bribery. Here, Ibo is a symbolic means of resistance against English and brings a sense of brotherhood and kinship. It is the Ibo, which tells Obi that Mr. Mark is an Ibo. Obi's statement, "I didn't think you were Ibo," or Mr. Mark declaration, "we are both Ibos and I cannot hide anything from you" (NLE 86) shows that this is the Ibo language which connects them. They might see each other on the street without knowing their sameness of tradition or culture, and only through language, these men identify themselves as the Ibo.

Obi rejects to take bribes from Mr. Mark and this rejection is shown by using English language: "I'm sorry, Mr Mark, but I really don't understand what you are driving at. He said this in English, much to Mr Mark's consternation" (NLE 79). However, when Obi studied in England, Ibo provided his satisfaction and he felt guilty about English:

He spoke Ibo whenever he had the least opportunity of doing so. Nothing gave him greater pleasure than to find another Ibo-speaking student in a London bus. Nevertheless, when he had to speak in English with a Nigerian student from another tribe he lowered his voice. It was humiliating to have to speak to one's countryman in a foreign language, especially in the presence of the proud owners of that language. (NLE 49)

When he returns to Nigeria, by adapting Westerns lifestyle and their informality, Obi takes a distance from his people and community. In Lagos, Obi selects English for most of his communication. Sometimes he is not able to find a suitable Ibo proverb when he wants to use it and Clara blames him: "I have always said you should go and study Ibo" (NLE 108). 
As a subject of his education, English becomes a means of social position and prestige for Obi after his return. English for Obi suggests the participation in "the shining elite" (NLE 98). There is a truth that English creates African 'European' and as "been-to," which is a local term for those who have 'been-to' the West. Obi feels he is a European and challenges his own traditional beliefs, such as marrying with an osu. Obi and some other characters like Christopher, use English language to show their power. Obi's authority is depicted through English language when he speaks with his servant, Sebastian:

'The fridge must be switched off at seven o'clock in the evening and on again at twelve noon. Do you understand?'

'Yes, sir. But meat no go spoil so?'

'No need to buy plenty meat at once.'

[...] 'Yes, sir. Only I tink you say I go de go market once every week.'

'I said nothing of the sort. I said I would only give you money once.' (NLE 100)

Obi stated in English while his servant speaks in Pidgin, because Pidgin brings a sense of un-authority and even inferiority. According to C. M. B. Brann, "Pidgin English has been used in Nigeria ever since the first Europe arrived. It has been employed all along the country as a diglossically Low language of informal oral communication" (qtd. in Bengoechea and Castillo Garcia 20). However, as a way to depict his relation with urban people, Obi shifts to Pidgin from English. For example when he speaks with the boys in the parking, "na me go look your car for you,' chorused three of them at once.' Ok, make you look am well" or when he talks with Sam Okoli's steward (NLE 110).

The hybridity of Obi's cultural identity and ambivalence of his situation is shown through intentional shift from English into Pidgin or Ibo and vice versa, and mispronunciation of English statements. Language connects an individual to his culture in multicultural community; therefore, language is a device to show different attitudes toward life. In colonial nations, using one language is difficult because there are different languages from different sources; therefore, a person's choice of a language reflects his cultural identity.

\section{Conclusion}

As shown in the previous sections, Achebe's depiction of Nigeria is very similar to what Edward Said's describes in Orientalism. Achebe has created a number of African and British characters and described their relationship and their attitudes towards each other in order to emphasize the dark aspects of colonialism. Among the British characters in the novel, the most interesting one is Mr. Green. As shown above, Mr. Green is the representative of British colonialists in Nigeria.

According to Achebe, Mr. Green is alike the British colonialists in Conrad's Heart of Darkness. Although he lives in Lagos and witnesses the progress in Nigeria, he still imagines Nigeria as a "dark" continent. For him, Africa is a primitive land dominated by darkness and thick bushes and needs the colonisers for light and civilization. However, Mr. Green is not alone in his illusions and he should not be blamed for his false notion about Africa. Like many other Europeans, he is affected by orientalist education and orientalist texts.

As discussed above, the black characters, too, are affected by colonization. For example, Nigerian people's expectation of Obi as a person who has just been graduated from an English university shocks him and makes many problems for him. Because the Nigerians think too highly of English language, England, and its universities, they expect Obi to be a superman. This shows the inferiority complex of the Nigerians. The stereotypical depiction of Africa and African people has created a false and negative self-image for the black people. Therefore, the experience of colonialism and the exposure to European culture has distorted African people's self-image. Achebe shows that the European study of African culture and people is based on the aims and intention of Western orientalists; it is based on a binary opposition of Europeans and non-Europeans.

\section{References}

Achebe, Ch. (1963). No Longer at Ease. London: Heinemann. Ashcroft, B et al. (2002). The Empire Writes Back. London: Routledge. Bengoechea, M., \& Gema S. Castillo Garcia. (2000) "The Semantic of Solidarity and Brotherhood in Chinua Achebe's No Longer at Ease". Journal of English Studies. II 19-34.

Fanon, F. (2008). Black Skin, White Masks. Transl. Charles Lam Markmann. London: Pluto P. ---. (1963). The Wretched of the Earth. Trans. Constance Farrington. New York: Grove P.

Loomba, A. (1998). Colonialism/ Postcolonialism. London: Routledge.

Memmi, A. (1991). The Coloniser and the Colonised. Boston: Beacon P.

Said, E W. (1978).Orientalism. New York: Penguin Books.

Thing'o, NW. (1987). Decolonising the Mind: The Politics of Language in African Literature. Zimbabwe Publishing House. 